\title{
Laju Timbulan dan Komposisi Sampah Rumah Tangga di Kecamatan Sukolilo Surabaya
}

\author{
Devy Safitri Ayu Hapsari dan Welly Herumurti \\ Departemen Teknik Lingkungan, Fakultas Teknik Sipil dan Perencanaan, Institut Teknologi Sepuluh \\ Nopember (ITS) \\ e-mail: devysah@gmail.com, herumurti@enviro.its.ac.id
}

\begin{abstract}
Abstrak-Kecamatan Sukolilo memiliki jumlah penduduk lebih dari seratus ribu jiwa dengan kepadatan penduduk yang cukup tinggi. Peningkatan jumlah penduduk juga diikuti dengan peningkatan laju timbulan sampah. Tujuan penelitian ini adalah menentukan timbulan dan komposisi sampah. Pengukuran laju timbulan sampah dilakukan dengan metode load count dan metode stratified random sampling sesuai SNI 19-3964-1994 dengan sampel sebanyak 150 KK. Pengukuran komposisi sampah dilakukan dengan metode yang terdapat di SNI 19-3964-1994. Hasil penelitian berupa laju timbulan sampah rumah tangga sebesar $0,38 \mathrm{~kg} /$ orang.hari. Komposisi sampah didominasi oleh sampah yang dapat dikomposkan, plastik, dan kertas. Densitas sampah didapatkan sebesar $146,02 \mathrm{~kg} / \mathrm{m}^{3}$.
\end{abstract}

Kata Kunci-densitas, komposisi, laju timbulan.

\section{PENDAHULUAN}

K ECAMATAN Sukolilo merupakan salah satu kecamatan di wilayah Surabaya Timur yang terdiri dari tujuh kelurahan. Kecamatan Sukolilo memiliki jumlah penduduk 115.855 jiwa dengan kepadatan penduduk 4.897 jiwa/ $\mathrm{km}^{2}$ [1]. Jumlah penduduk yang semakin banyak menyebabkan pembangunan di Kecamatan Sukolilo menjadi semakin pesat. Salah satu buktinya adalah jumlah perkampungan dan perumahan yang semakin banyak. Jumlah timbulan sampah rata - rata harian di Kecamatan Sukolilo pada tahun 2012 adalah sebesar 326,54 m/hari atau menyumbang $3,16 \%$ dari jumlah timbulan total Kota Surabaya per harinya [2].

Adanya pertambahan jumlah perkampungan dan perumahan di Kecamatan Sukolilo menyebabkan bertambahnya jumlah timbulan sampah yang dihasilkan sehingga diperlukan sistem pengumpulan sampah yang baik untuk mengelola sampah di perkampungan dan perumahan. Besarnya timbulan sampah rumah tangga kota besar adalah 0,4-0,5 kg/orang.hari [3], apabila dibandingkan dengan timbulan sampah di Surabaya Timur yaitu 0,33 kg/orang.hari [4]. Jumlah timbulan sampah bepengaruh pada kebutuhan alat pengumpul yang lebih banyak. Besarnya jumlah timbulan sampah rata-rata harian di perkampungan dan perumahan di Kecamatan Sukolilo pada tahun 2017 belum pernah diukur, sehingga perlu dilakukannya analisis lebih lanjut untuk menganalisis laju timbulan dan komposisi sampah di perkampungan dan perumahan yang berada di Kecamatan Sukolilo.

\section{METODE PENELITIAN}

\section{A. Penentuan Wilayah Penelitian}

Penentuan wilayah penelitian didasarkan pada pengamatan langsung saat pemetaan TPS dan mencari informasi mengenai keadaan daerah dan penduduk melalui data dari kantor kecamatan dan kelurahan. Jumlah Tempat Penampungan Sementara (TPS) di Kecamatan Sukolilo sebanyak 8 TPS yaitu TPS ITS, TPS IPLT Keputih, TPS Gebang Putih, TPS Klampis Ngasem, TPS Semolowaru, TPS Semolowaru Bahari, TPS Medokan Semampir, dan TPS Asrama Brimob. Penentuan jumlah sampel sampah yang akan diambil menggunakan metode yang terdapat pada SNI 19-3964-1994. Pengambilan sampel dilakukan dengan metode stratified random sampling atau dilakukan secara acak. Jumlah sampel yang diambil sebanyak $150 \mathrm{KK}$, terdiri dari satu perkampungan dan dua perumahan. Pembagian jumlah sampel dapat dilihat pada Tabel 1.

Tabel 1.

Pembagian Jumlah Sampel per Kawasan

\begin{tabular}{lcc}
\multicolumn{2}{c}{ Pembagian Jumlah Sampel per Kawasan } \\
& Kawasan & $\begin{array}{c}\text { Jumlah } \\
\text { KK }\end{array}$ \\
\hline Perkampungan & 50 \\
Perumahan & & 100 \\
\hline & Total & 150
\end{tabular}

B. Pengukuran Timbulan, Komposisi Sampah, dan Sistem Pengumpulan Sampah

Pengukuran timbulan sampah dilakukan di sumber dan di TPS. Pengambilan sampel laju timbulan sampah dilakukan selama dua belas hari di satu wilayah perkampungan dan dua wilayah perumahan. Metode pengambilan sampel yang digunakan adalah metode stratified random sampling dan metode load count. Densitas sampah didapatkan dari densitas rata-rata load count seluruh gerobak sampah yang diukur berat sampahnya.

Pengambilan data pengukuran komposisi sampah dilakukan di TPS. Pengambilan sampel dilakukan dengan menentukan gerobak sampah yang akan diambil sampahnya Gerobak sampah yang dipilih merupakan gerobak yang telah diikuti untuk pemgambilan data pengukuran rute. Sampel sampah diambil dari satu unit gerobak sampah. Sebelum dimasukkan ke dalam kotak densitas $40 \mathrm{~L}$, sampah ditimbang dan dicatat beratnya menggunakan neraca massa $30 \mathrm{~kg}$. Selanjutnya sampah tersebut dimasukkan ke kotak densitas dan diukur tinggi sampahnya. Selanjutnya sampah dipilah berdasarkan jenis-jenis sampah yang telah 
ditentukan. Sampah yang telah terpilah kemudian ditimbang menggunakan neraca massa $30 \mathrm{~kg}$ dan dicatat berat masingmasing jenis sampahnya. Perhitungan persentase tiap komponen sampah menggunakan persamaan berikut ini.

$\%$ Komponen sampah $=\frac{\text { berat sampah tiap komponen }(\mathrm{kg})}{\text { berat sampah total }(\mathrm{kg})} \times 100 \%$

\section{HASIL DAN PEMBAHASAN}

\section{A. Laju Timbulan Sampah Rumah Tangga}

Berat sampah yang dihasilkan setiap rumah di Kecamatan Sukolilo berbeda-beda. Hal ini disebabkan oleh jumlah sampah yang dihasilkan setiap rumahnya. Jumlah penghuni di setiap rumah merupakan faktor yang paling utama dalam besarnya timbulan sampah rumah tangga. Tren jumlah timbulan sampah berbeda-beda, dikarenakan variasi dalam pola konsumsi masyarakat di lokasi atau sumber yang berbeda yang diikuti pula dengan perubahan gaya hidup masyarakatnya [5]. Hasil pengukuran laju timbulan sampah rumah tangga di perkampungan dan perumahan yang terdapat di Kecamatan Sukolilo sama, yaitu 0,38 kg/orang.hari. Hal ini dikarenakan aktivitas dan jumlah sampah yang dihasilkan di perumahan dan perkampungan hampir sama. Laju timbulan sampah di perkampungan dan perumahan di Kecamatan Sukolilo lebih kecil dibandingkan laju timbulan sampah rumah tangga di Indonesia, yaitu 0,61 $\mathrm{kg}$ /orang.hari [6]. Besar laju timbulan sampah rumah tangga di Kecamatan Sukolilo hampir sama dengan laju timbulan sampah rumah tangga di Kecamatan Genteng yaitu 0,35 kg/orang.hari [7]. Sedangkan laju timbulan sampah rumah tangga di Kecamatan Sukolilo lebih besar dari laju timbulan di Kecamatan Tambaksari, Kecamatan Rungkut, dan Kecamatan Semampir, masing-masing adalah 0,27 kg/orang.hari [8], 0,31 kg/orang.hari [9], dan 0,228 kg/orang.hari [10]. Hasil laju timbulan sampah di perkampungan dan perumahan yang ada di Kecamatan Sukolilo dapat dilihat pada Tabel 2.

Sampling laju timbulan sampah dilakukan selama dua belas hari di satu wilayah perkampungan dan dua wilayah perumahan. Pada hari pertama hingga keempat dilakukan sampling di perkampungan yaitu Keputih gang I di Kelurahan Keputih sedangkan hari kelima hingga ketujuh dilakukan di Perumahan Dosen ITS Blok U. Pada hari kedelapan hingga hari kedua belas dilakukan di Perumahan Wisma Mukti Klampis. Metode pengambilan sampel yang digunakan adalah stratified random sampling dan metode load count. Metode stratified random sampling digunakan pada hari kesepuluh hingga hari kedua belas, sedangkan metode load count digunakan pada hari kesatu hingga hari kesembilan. Laju timbulan sampah didapatkan dari berat sampah di gerobak dikalikan dengan jumlah penduduk pada lokasi sampling. Berdasarkan Tabel 2, didapatkan laju timbulan sampah perkampungan dan perumahan yang berada di Kecamatan Sukolilo sama, yaitu 0,38 $\mathrm{kg} /$ orang.hari.
Tabel 2.

Laju Timbulan sampah Perkampungan dan Perumahan di Kecamatan Sukolilo

\begin{tabular}{|c|c|c|c|c|}
\hline $\begin{array}{l}\text { Sampling hari ke - } \\
\text { Sumber }\end{array}$ & $\begin{array}{l}\text { Berat sampah } \\
\quad(\mathrm{kg} / \mathrm{hari})\end{array}$ & $\begin{array}{l}\text { Jumlah } \\
\text { Penduduk } \\
\text { (orang) }\end{array}$ & $\begin{array}{l}\text { Laju Timbulan } \\
\text { sampah } \\
\text { (kg/orang.hari) }\end{array}$ & $\begin{array}{c}\text { Laju Timbulan } \\
\text { Per Kawasan } \\
\text { (kg/orang.hari) }\end{array}$ \\
\hline $\begin{array}{l}1 \text { - Perkampungan } \\
\text { (Keputih Gang I) }\end{array}$ & 57,135 & 135 & 0,42 & \multirow{4}{*}{0,38} \\
\hline $\begin{array}{l}2 \text { - Perkampungan } \\
\text { (Keputih Gang I) }\end{array}$ & 58,097 & 135 & 0,43 & \\
\hline $\begin{array}{l}3 \text { - Perkampungan } \\
\text { (Keputih Gang I) }\end{array}$ & 60,411 & 262 & 0,23 & \\
\hline $\begin{array}{l}4 \text { - Perkampungan } \\
\text { (Keputih Gang I) }\end{array}$ & 58,447 & 135 & 0,43 & \\
\hline $\begin{array}{l}5 \text { - Perumahan } \\
\text { (Perumahan Dosen ITS } \\
\text { Blok U) }\end{array}$ & 140,71 & 315 & 0,44 & \multirow{8}{*}{0,38} \\
\hline $\begin{array}{l}6 \text { - Perumahan } \\
\text { (Perumahan Dosen ITS } \\
\text { Blok U) }\end{array}$ & 139,392 & 315 & 0,44 & \\
\hline $\begin{array}{l}7 \text { - Perumahan } \\
\text { (Perumahan Dosen ITS } \\
\text { Blok U) }\end{array}$ & 142,071 & 441 & 0,32 & \\
\hline $\begin{array}{l}8 \text { - Perumahan (Wisma } \\
\text { Mukti) }\end{array}$ & 186,561 & 507 & 0,37 & \\
\hline $\begin{array}{l}9 \text { - Perumahan } \\
\text { (Wisma Mukti) }\end{array}$ & 167,19 & 507 & 0,33 & \\
\hline $\begin{array}{l}10-\text { Perumahan } \\
\text { (Wisma Mukti) }\end{array}$ & 88,687 & 240 & 0,37 & \\
\hline $\begin{array}{l}11 \text { - Perumahan } \\
\text { (Wisma Mukti) }\end{array}$ & 90,287 & 240 & 0,38 & \\
\hline $\begin{array}{l}12 \text { - Perumahan } \\
\text { (Wisma Mukti) }\end{array}$ & 86,94 & 240 & 0,36 & \\
\hline
\end{tabular}

Selain data laju timbulan perkampungan dan perumahan di Kecamatan Sukolilo, juga dilakukan pengambilan data timbulan per TPS di Kecamatan Sukolilo melalui mapping TPS. Berikut ini data timbulan sampah per TPS yang dapat dilihat pada Tabel 3 .

Tabel 3.

Timbulan Sampah Per TPS di Kecamatan Sukolilo

\begin{tabular}{lcccc}
\hline \multicolumn{1}{c}{ Nama TPS } & $\begin{array}{c}\text { Jumlah } \\
\text { Ritasi }\end{array}$ & $\begin{array}{c}\text { Volume } \\
\text { sampah } \\
(\mathrm{m} 3)\end{array}$ & $\begin{array}{c}\text { Densitas } \\
(\mathrm{kg} / \mathrm{m} 3)\end{array}$ & $\begin{array}{c}\text { Timbulan } \\
(\mathrm{kg} / \mathrm{hari})\end{array}$ \\
\hline ITS & 13 & 17,41 & 2542,20 \\
Semolowaru & 22 & 27,27 & 3981,95 \\
$\begin{array}{l}\text { IPLT Keputih } \\
\text { Tinja }\end{array}$ & 13 & 31,71 & & 4630,28 \\
Klampis & 21 & 34,42 & & 5026,01 \\
$\begin{array}{l}\text { Medokan } \\
\text { Semampir }\end{array}$ & 30 & 30,30 & 146,02 & 4424,39 \\
Gebang Putih & 22 & 22,22 & & 3244,55 \\
Semolowaru & 13 & 15,23 & & 2223,88 \\
Bahari & 2 & 2,62 & & 382,57 \\
Asrama Brimob & 121 & 181,18 & 26455,83 \\
\hline Total & & & \\
\hline
\end{tabular}

Perhitungan timbulan sampah di TPS dapat dilakukan dengan mengalikan volume sampah yang masuk ke TPS per hari dengan densitas rata-rata hasil dari load count seluruh gerobak. TPS Asrama Brimob menghasilkan volume sampah terkecil dalam 1 hari yaitu $2,62 \mathrm{~m}^{3} /$ hari sehingga timbulan TPS Asrama Brimob adalah 382,57 kg/hari. TPS ITS menghasilkan volume sampah sebesar $17,41 \mathrm{~m}^{3} /$ hari sehingga didapatkan timbulan TPS ITS sebesar 2542,20 $\mathrm{kg} / \mathrm{hari}$. Volume sampah yang masuk ke TPS Semolowaru dalam 1 hari adalah $27,27 \mathrm{~m}^{3}$ /hari sehingga didapatkan timbulan TPS Semolowaru sebesar 3981,95 kg/hari. Timbulan TPS IPLT keputih Tinja menghasilkan volume 
sampah sebesar $31,71 \mathrm{~m}^{3} /$ hari sehingga timbulan yang dihasilkan sebesar 4630,28 kg/hari. Timbulan terbesar dihasilkan oleh TPS Klampis yaitu 5026,01 kg/hari. Hal ini dikarenakan area pelayanan TPS Klampis besar sehingga volume sampah yang masuk ke TPS Klampis cukup besar yaitu 34,42 $\mathrm{m}^{3} /$ hari. TPS Medokan Semampir menghasilkan volume sampah yang cukup besar yaitu $30,3 \mathrm{~m}^{3} / \mathrm{hari}$ sehingga didapatkan timbulan TPS Medokan Semampir sebesar 4424,39 kg/hari. TPS Gebang Putih menghasilkan volume sampah sebesar $22,22 \mathrm{~m}^{3} /$ hari sehingga didapatkan timbulan TPS Gebang Putih sebesar 3244,55 kg/hari. TPS Semolowaru Bahari menghasilkan volume sampah yaitu $15,23 \mathrm{~m}^{3} /$ hari sehingga didapatkan timbulan TPS Semolowaru Bahari sebesar 2223,88 kg/hari. Total timbulan sampah yang masuk ke TPS di Kecamatan Sukolilo adalah $26455,83 \mathrm{~kg} / \mathrm{hari}$.

\section{B. Densitas Sampah Rumah Tangga}

Densitas sampah sangat penting sebagai parameter terintegrasi dengan sistem perencanaan pengelolaan sampah. Perhitungan densitas sampah dapat dilakukan dengan membagi berat sampah satu gerobak dengan volume sampah yang ada di gerobak di TPS. Pengukuran densitas dilakukan bersamaan dengan pengukuran laju timbulan sampah. Didapatkan densitas rata-rata sampah rumah tangga sebesar $146,02 \mathrm{~kg} / \mathrm{m}^{3}$. Hasil perhitungan densitas sampah dapat dilihat pada Tabel 4.

Tabel 4.

Densitas Sampah di TPS Kecamatan Sukolilo

\begin{tabular}{cclccc}
\hline No & $\begin{array}{c}\text { Nama } \\
\text { TPS }\end{array}$ & Sumber Sampah & $\begin{array}{c}\text { Berat } \\
\text { Tiap } \\
\text { Gerobak } \\
(\mathrm{kg})\end{array}$ & $\begin{array}{c}\text { Volume } \\
\text { Tiap } \\
\text { Gerobak } \\
\left(\mathrm{m}^{3}\right)\end{array}$ & $\begin{array}{c}\text { Densitas } \\
\text { Tiap } \\
\text { Gerobak } \\
\left(\mathrm{kg} / \mathrm{m}^{3}\right)\end{array}$ \\
\hline 1 & ITS & Perumdos blok U & 281,42 & 1,26 & 223,35 \\
2 & ITS & Keputih Gang 1 & 114,27 & 1,26 & 90,69 \\
3 & Klampis & Perumahan Wisma Mukti & 186,56 & 1,31 & 142,41 \\
4 & Klampis & Perumahan Wisma Mukti & 167,19 & 1,31 & 127,63 \\
\hline \multicolumn{5}{c}{ Densitas Rata-Rata } \\
\hline \multicolumn{5}{c}{} \\
\hline
\end{tabular}

\section{Komposisi Sampah Rumah Tangga}

Analisis mengenai komposisi sampah rumah tangga di Kecamatan Sukolilo dilakukan dengan pemilahan sampah. Pemilahan sampah dilakukan dengan membagi sampah menjadi beberapa jenis, antara lain plastik (HDPE plastik, HDPE botol, HDPE alumunium, LDPE, PET warna, PET transparan, PS sterofoam, PP bag, plastik lainnya), sampah yang dapat dikomposkan (sisa makanan dan sampah kebun), kertas (koran, hvs, duplek, tetrapack, karton, kertas lainnya, dan tisu), logam (besi, kaleng, kaleng cans, kabel tembaga), diapers (popok dan pembalut), kain, kaca (botol kaca dan kaca lain), karet, sampah B3, dan residu. Perhitungan komposisi sampah didapatkan dengan membandingkan berat setiap jenis sampah dengan berat total sampah yang dihasilkan. Komposisi sampah dinyatakan dalam persentase (\%). Komposisi sampah rumah tangga di Kecamatan Sukolilo dibedakan menjadi dua jenis yaitu komposisi sampah perkampungan dan komposisi sampah perumahan.

\section{- Komposisi Sampah Perkampungan}

Perhitungan komposisi sampah untuk perkampungan dilaksanakan di Keputih Gang I. Pengambilan data dilakukan dengan memilah sampah dalam satu gerobak sampah yang melayani area Keputih Gang I selama 4 hari. Tabel 5 adalah hasil dari analisis komposisi sampah yang berasal dari perkampungan.
Tabel 5.

Komposisi Sampah Perkampungan di Kecamatan Sukolilo

\begin{tabular}{lc}
\hline Komposisi Sampah & Perkampungan \\
\hline Dapat Dikomposkan & $75 \%$ \\
Plastik & $11 \%$ \\
Kertas & $7 \%$ \\
Logam & $1 \%$ \\
Kaca & $1 \%$ \\
Kain & $1 \%$ \\
Kayu & $1 \%$ \\
Karet & $0 \%$ \\
Diapers & $1 \%$ \\
Lain-lain & $1 \%$ \\
B3 & $0 \%$ \\
\hline
\end{tabular}

Rata-rata komposisi sampah perkampungan di Kecamatan Sukolilo terdiri atas sampah yang dapat dikomposkan sebesar $75 \%$, plastik $11 \%$, kertas $7 \%$, diapers $1 \%$, logam, kain, kayu dan kaca masing-masing $1 \%$, serta residu $1 \%$. Komposisi terbesar sampah perkampungan adalah sampah yang dapat dikomposkan. Tingginya persentase sampah yang dapat dikomposkan karena setiap harinya masyarakat menghasilkan sampah sisa makanan yang besar dan merupakan kebutuhan sehari-hari. Selain itu, pengelolaan sampah sisa makanan belum maksimal sehingga yang dikumpulkan ke TPS memiliki jumlah yang besar.

- Komposisi Sampah Perumahan

Perhitungan komposisi sampah untuk perumahan dilaksanakan di Perumahan Wisma Mukti Klampis dan Perumahan Dosen ITS Blok U selama 7 hari. Pengambilan data dilakukan dengan memilah sampah dalam satu gerobak sampah yang melayani area Perumahan Wisma Mukti Klampis dan Perumahan Dosen ITS Blok U, serta sampah yang berasal dari $50 \mathrm{KK}$ yang ada di Perumahan Wisma Mukti Klampis. Tabel 6 adalah hasil persentase komposisi sampah perumahan.

Tabel 6.

Komposisi Sampah Perumahan di Kecamatan Sukolilo

\begin{tabular}{lc}
\hline Komposisi Sampah & Perumahan \\
\hline Dapat Dikomposkan & $74 \%$ \\
Plastik & $11 \%$ \\
Kertas & $9 \%$ \\
Logam & $1 \%$ \\
Kaca & $1 \%$ \\
Kain & $0 \%$ \\
Kayu & $1 \%$ \\
Karet & $0 \%$ \\
Diapers & $2 \%$ \\
Lain-lain & $1 \%$ \\
B3 & $0 \%$ \\
\hline
\end{tabular}

Komposisi terbesar sampah perumahan adalah sampah yang dapat dikomposkan. Jenis sampah yang dapat dikomposkan adalah sisa makanan dan sampah kebun. Tingginya persentase sampah yang dapat dikomposkan karena setiap harinya masyarakat menghasilkan sampah sisa makanan yang besar. Selain itu terdapat rumah makan di sekitar lokasi sampling. Hasil dari komposisi sampah perkampungan dan perumahan yang terdapat di Kecamatan Sukolilo hampir sama. Komposisi sampah perkampungan 
dan perumahan di Kecamatan Sukolilo didominasi oleh sampah yang dapat dikomposkan, plastik, dan kertas.

\section{KESIMPULAN}

Berdasarkan penelitian yang telah dilakukan, dapat diambil kesimpulan untuk rata-rata laju timbulan sampah rumah tangga di Kecamatan Sukolilo adalah 0,38 $\mathrm{kg}$ /orang.hari dengan komposisi sampah yang didominasi oleh sampah yang dapat dikomposkan, plastik, dan kertas. Densitas sampah rumah tangga di Kecamatan Sukolilo adalah $146,02 \mathrm{~kg} / \mathrm{m}^{3}$.

\section{DAFTAR PUSTAKA}

[1] Badan Pusat Statistik Kota Surabaya, Kecamatan Sukolilo dalam Angka 2016. 2016.

[2] Dinas Kebersihan dan Pertamanan Kota Surabaya, Timbulan Sampah Per Kecamatan Kota Surabaya Tahun 2012. 2012.

[3] Badan Standarisasi Nasional, SNI 3242-2008 Pengelolaan
Sampah di Permukiman. 2008.

[4] S. Dhokhikah, Y., Trihadiningrum, Y., Sunaryo, "Community participation in household solid waste reduction in Surabaya," Resour. Conserv. Recycl., vol. 102, pp. 153-162, 2015.

[5] L. Purcell, M., Magette, M., Prediction of household and commercial BMW generation according to socio-economic and other factors for the Dublin region. Waste Management 29, 2009.

[6] W. Purwanta, "Perhitungan Emisi Gas Rumah Kaca dari Sektor Sampah Perkotaan di Indonesia," J. Tek. Lingkung., vol. 10, pp. 01-08, 2009.

[7] F. B. Maziya, "Emisi Gas Rumah Kaca dari Pengelolaan Sampah Domestik Kecamatan Genteng Surabaya Pusat," Institut Teknologi Sepuluh Nopember, 2013.

[8] N. Setiadewi, "Pengaruh SPA Terhadap Pengelolaan Sampah Permukiman Kecamatan Tambaksari," Institut Teknologi Sepuluh Nopember, 2014.

[9] Y. P. Ratih, "Perencanaan Fasilitas Pengolahan Sampah Rumah Tangga di Kecamatan Rungkut Surabaya," Institut Teknologi Sepuluh Nopember, 2013

[10] N. A. Maulidia, "Potensi Reduksi dan Pengumpulan Sampah Rumah Tangga di Kecamatan Semampir Surabaya," Institut Teknologi Sepuluh Nopember, 2016. 